Lasse Lindekilde

\title{
SOFT REPRESSION AND MOBILIZATION: \\ THE CASE OF TRANSNATIONAL ACTIVISM \\ OF DANISH MUSLIMS DURING THE CARTOONS CONTROVERSY
}

This article delivers an empirical analysis of the effects of Danish Muslims' transnational activities during the Muhammad cartoons controversy in 2005-6 on subsequent Muslim claims making in Denmark. The article argues that the envisioned "boomerang effect" of the transnational activities - the attempt to put pressure on Danish authorities by contacting political and religious authorities in the Middle East—backfired on Danish Muslims. The transnational move was successfully "securitized" by elements of the media and the political elite, inviting soft forms of repression against the Muslim actors, especially those involved in the "imam delegations" that traveled to Egypt, Lebanon, and Syria in December 2005. These actors were forced into a more defensive mode of claims making soon after their return to Denmark through processes of name calling and stigmatization. Building on this case study, the article concludes by suggesting some theoretical modifications/specifications to the boomerang model of transnational activism. 